\title{
COMMENTS
}

\section{Limited Partnerships and Federal Diversity Jurisdiction}

Unincorporated associations, ${ }^{1}$ unlike corporations, are not regarded as citizens for purposes of determining federal jurisdicton based on diversity of citizenship. Although many unincorporated associations can sue and be sued in the association name, ${ }^{2}$ the law of diversity jurisdiction treats them as aggregates of individuals: in an action by or against an unincorporated association the relevant citizenship for diversity purposes is the citizenship of each of the "persons composing" the association. "The practical effect of this treatment, given the extended rule of Strawbridge $v$. Curtiss ${ }^{4}$ that diversity jurisdiction does not attach unless the citizenship of each party is diverse from that of each opposing party, is to close the federal diversity jurisdiction to many large unincorporated associations.

In Colonial Realty Corp. v. Bache \& Co., ${ }^{5}$ the Second Circuit mitigated the effects upon modern limited partnerships of the unincorporated association rule by holding that the persons composing a limited partnership for purposes of diversity jurisdiction are the general partners only. The Third Circuit in the recent case of Carlsberg Resources Corp. v. Cambria Savings \& Loan Association ${ }^{6}$ has rejected Colonial Realty's application of the unincorporated association rule, and has held that in a suit involving a limited partnership the relevant citizenship is not only that of the general partners, but that of the limited partners as well.

This comment examines the principles underlying the diversity rules for both incorporated and unincorporated associations, and evaluates the Colonial Realty and Carlsberg Resources decisions in light of those principles. The comment embraces the general rule set

' Collected under the term "unincorporated associations" are such diverse non-corporate entities as joint stock companies, business trusts, partnerships, limited partnerships, labor unions, and fraternal organizations.

2 See, e.g., the following "common name" statutes conferring on partnerships the capacity to sue and be sued in partnership name: Conn. Gen. STat. ANN. \$ 52-112 (West 1960); Mich. Comp. Laws AnN. \$ 600.2051(2) (1968); N.Y. Civ. Prac. Law $\$ 1025$ (McKinney 1976).

${ }^{3}$ E.g., Great Southern Fire Proof Hotel Co. v. Jones, 177 U.S. 449 (1900).

+7 U.S. (3 Cranch) 267 (1806).

5 358 F.2d 178 (2d Cir.), cert. denied, 385 U.S. 817 (1966).

- 554 F.2d 1254 (3d Cir. 1977), aff'g 413 F. Supp. 880 (W.D. Pa. 1976). 
forth by the dissenting opinion in Carlsberg Resources, and concludes by suggesting how that rule should be applied in cases involving limited partnerships and modern business trusts.

\section{Unincorporated Associations and the Complete Diversity REQUIREMENT}

Original jurisdiction over questions involving parties of "diverse" citizenship was first vested in the federal courts by the Judiciary Act of 1789.7 Since that time, despite recurring criticism of the policy underlying diversity jurisdiction, ${ }^{8}$ actions between citizens of different states have been maintainable in federal courts. ${ }^{9}$ Congress, however, has never granted the courts the broadest possible diversity jurisdiction permitted by the Constitution. Amendments to the Judiciary Act have traced a pattern first of expansion, ${ }^{10}$ then contraction" ${ }^{\text {" }}$ of the scope of the jurisdiction.

Supreme Court decisions have had a profound impact on the bounds of the diversity jurisdiction. The most significant judicial gloss on the diversity statute was the Strawbridge "complete diversity" requirement, which "forbids suits in the federal courts unless

7 The Judiciary Act of 1789 , ch. $20, \S 11,1$ Stat. $73,(1789-1799)$, provided for jurisdiction of the federal courts when "the suit is between a citizen of the State where the suit is brought, and a citizen of another State." Specific authority for diversity jurisdiction derives from article III of the Constitution, which provides, inter alia, that "[t]he judicial Power shall extend to . . . Controversies . . . between Citizens of different States." U.S. Const. art. 3, $\$ 2$.

${ }^{3}$ Recently, Chief Justice Burger has announced that the Judicial Conference of the United States will recommend that Congress abolish diversity jurisdiction. U.S. Supreme Court, Public Information Office, Release of March 11, 1977, noted in Carlsberg Resources Corp. v. Cambria Sav. \& Loan Ass'n, 554 F.2d 1254, 1263 n.4 (3d Cir. 1977). See Lumberman's Mut. Cas. Co. v. Elbert, 348 U.S. 48, 53-60 (1954) (Frankfurter, J. concurring); cf. Currie, The Federal Courts and the American Law Institute (part I), 36 U. CHI. L. Rev. 1, 6 8 (1968) (notes difficulty of defining limits of jurisdiction). But see Moore \& Weckstein, Corporations and Diversity of Citizenship Jurisdiction: A Supreme Court Fiction Revisited, 77 HaRv. L. REv. 1426, 1449-51 (1964).

- The current diversity statute is at 28 U.S.C. $\$ 1332$ (1970). Section 1332(a) provides in pertinent part that "[t]he district courts shall have original jurisdiction of all civil actions where the matter in controversy exceeds the sum or value of $\$ 10,000$, exclusive of interest and costs, and is between . . . citizens of different States."

10 The grant of diversity jurisdiction was broadened significantly by the Act of March 3, 1875 , ch. 137, \$1, 18 Stat. (pt. 3) 470 (1875), which eliminated the requirement that one party be a citizen of the forum state, requiring instead only a controversy "between citizens of different States." Id.

"The jurisdictional amount in controversy has been increased from $\$ 500$ under the Judiciary Act of 1789 , ch. $20, \S 11,1$ Stat. 73 (1789-99) to $\$ 10,000$ under the current statute, 28 U.S.C. $\$ \$ 1331$ (a), 1332(a) (1970). The 1958 amendments to the jurisdictional statute also narrowed the scope of diversity actions by providing that a corporation is deemed a citizen of the state of its principal place of business as well as of its state of incorporation. Pub. L. No. 85-554, \$ 2, 72 Stat. 415 (1958) (codified at 28 U.S.C. $\S 1332$ (c) (1970)). 
all the parties on one side are of citizenship diverse to those on the other side."12 The complete diversity requirement, in turn, opened up a difficult new field of jurisdictional jurisprudence devoted to the question of whose citizenship matters in multiparty lawsuits. ${ }^{13} \mathrm{~A}$ most troublesome conceptual problem arose in cases involving associations, both incorporated and unincorporated: does the association have citizenship for purposes of the diversity statute ${ }^{14}$ or must the court look to the citizenship of its individual members? The Court resolved the issue of corporate citizenship over 120 years ago in Marshall v. Baltimore \& Ohio Railroad, ${ }^{15}$ by announcing a rule which effectively treated corporations as citizens of the state of incorporation. The Court has consistently refused, however, to extend the Marshall approach to unincorporated associations.

\section{A. Corporate Citizenship and Diversity Jurisdiction}

The Supreme Court first considered the problem of corporate citizenship in Bank of the United States v. Deveaux, ${ }^{16}$ an action by a Pennsylvania corporation against individuals who were citizens of Georgia. The Court concluded that, although a corporation as a distinct legal entity was not a citizen within the meaning of the Constitution or the Judiciary Act, it could invoke diversity jurisdiction on the basis of the citizenship of its individual corporate shareholders. ${ }^{17}$ Looking through the corporate entity to its constituent members, the Court found that an action to which a corporation is a party is "in fact and in law" an action by or against "those persons suing in their corporate character, by their corporate name for a corporate right."18

${ }_{12}$ Treinies v. Sunshine Mining Co., 308 U.S. 66, 71 (1939).

${ }^{13}$ The question of whose citizenship counts would have far less importance were it not for Strawbridge. Before Strawbridge, jurisdiction could be invoked upon the finding that one party was diverse from a single opposing party. Obviously, very hard questions about relevant citizenship would seldom be reached under such a rule. The Strawbridge rule requires reaching those questions in every case.

"Neither the Constitution nor the Judiciary Act defined the word "citizen" until the 1958 amendment to the Judiciary Act provided a rule for fixing corporate citizenship.

is 57 U.S. (16 How.) 314 (1853). See text and notes at notes 22-29 \& 136-137 infra.

16 9 U.S. (5 Cranch) 61 (1809) (Marshall, C.J.).

17 Id. at $86-87,91-92$.

is Id. at 87 . Chief Justice Marshall seems to have stretched reality in reaching this result. A suit by or against a corporation is neither procedurally nor substantively a suit by or against the shareholders. Green, Corporations as Persons, Citizens and Possessors of Liberty, 94 U. PA. L. Rev. 202, 213 (1946). In effect, the Court treated the shareholders as partners for purposes of establishing jurisdiction, McGovney, A Supreme Court Fiction (pt. 1), 56 Harv. L. REv. 853, 868 (1943), even though shareholders, unlike partners, may not be joined and sued to enforce an entity liability. Conversely, shareholders may not join or sue as a class to enforce a corporate claim, except in a shareholders' derivative suit, where the action belongs to the corporation and any judgment redounds to its benefit. 
With the growth of interstate commerce and the increasing dispersion of the ownership of corporate stock, the requirement of complete diversity of all shareholders came to effectively preclude many corporations from invoking the diversity jurisdiction of the federal courts. Noting the widespread criticism of the Strawbridge and Deveaux decisions, the Supreme Court in Louisville, Cincinnati \& Charleston Railroad $v$. Letson ${ }^{19}$ reexamined the relationship between the corporation and its shareholders, and the significance of that relationship for purposes of the diversity statute. The Court stated that the shareholders had enough of an interest in the action that their citizenship could, through the medium of the corporation, satisfy the jurisdictional requirement of an action "between citizens," but added that the citizenship of one or more of them could not be pleaded to defeat jurisdiction since they were not parties to the action..$^{20}$ The Court held that a corporation, as an artificial entity, should be deemed a citizen of the state of its incorporation for jurisdictional purposes. ${ }^{21}$

In Marshall v. Baltimore \& Ohio Railroad, ${ }^{22}$ the Supreme Court again faced the corporate citizenship problem. Although it rejected the proposition stated in Letson that a corporation was a citizen of its state of incorporation, the Court nevertheless concluded that diversity jurisdiction could not be defeated by the citizenship of the shareholders. The Court noted at the outset that although a corporation is not itself a citizen, one who deals with a corporation does not deal with a "mere metaphysical abstraction" but with directors and officers, the representatives of the shareholders, whose citizenship satisfies the constitutional requirement of a controversy "between Citizens." 23 The Court then spoke to the propriety of de-

1943 U.S. (2 How.) 497 (1844).

20 Id. at 554 .

${ }^{21}$ Id. at 555. The holding of the case does not seem to follow from the reasoning that precedes it. It is unclear how the Court got from its analysis of the interest and role of the shareholders to the conclusion that a corporation is to be deemed a citizen. The source of the confusion in this case is that the Court faced three distinct issues: (1) whether a suit involving a corporation as a party met the constitutional requirement of a suit "between Citizens"; (2) whether the provision of $\S 11$ of the Judiciary Act requiring " $a$ citizen of the State where the suit is brought" meant that every shareholder (or any shareholder) must be a citizen of that state; and (3) whether the statutory requirement (as construed by Strawbridge) of a controversy between citizens of different states required diversity of all the shareholders. Although the Court's reasoning only supported the holding with respect to the first of these issues, the Court regarded all three issues as resolved. Thus, concerning the issue of complete diversity, the Court said: "Our conclusion makes it unnecessary for us to consider that averment in the plea which denies jurisdiction on the ground that citizens of the same state with the plaintiff are members of corporations . . . which are members of [defendant]." Id. at 559.

$=57$ U.S. (16 How.) 314 (1853).

2 Id. at 327 . 
termining jurisdiction on the basis of the citizenship of the shareholders, who exercise no control over the litigation:

[R]epresentatives of numerous unknown and everchanging associates should [not] be permitted to allege the different citizenship of one or more of these stockholders to defeat [jurisdiction]. It is true that these stockholders are corporators, and represented by this "juridical person" and come under the shadow of its name. But for all the purposes of acting, contracting, and judicial remedy, they can speak, act, and plead, only through their representatives or curators. ${ }^{24}$

Since, under then-controlling precedent, a corporation had no juridical existence outside the state of its creation, ${ }^{25}$ the Court concluded that those "persons who act under these [corporate] faculties and use this corporate name, may be justly presumed to be resident" in that state. ${ }^{26}$

Although the reasoning of Marshall differed from that of Letson, the result reached was identical to that achieved by deeming a corporation to be a citizen. Supreme Court decisions after Letson variously interpreted that decision, ${ }^{27}$ but by 1895 the Court had settled on the view that a corporation, although not a citizen, could effectively invoke jurisdiction on the basis of the Marshall presumption. ${ }^{28}$ When Congress amended the diversity statute in 1958 to define corporate citizenship, however, the Senate Judiciary Committee stated that "[i]t is now established doctrine that a corporation, for the purposes of jurisdiction, is deemed a citizen of the State in which it is incorporated." ${ }^{29}$ The jurisdictional statute for corporations now states that "a corporation shall be deemed a citizen of any State by which it has been incorporated and of the State where it has its principal place of business."30

${ }^{24}$ Id. at 328.

${ }^{25}$ Id. (citing Bank of Augusta v. Earle, 38 U.S. (13 Pet.) 519 (1839)).

237 U.S. (16 How.) at 328. See generally Mason v. American Express Co., 334 F.2d 392, 394 n.4 (2d Cir. 1964).

${ }^{27}$ Compare Rundle v. Delaware \& Raritan Canal Co., 55 U.S. (14 How.) 80, 95 (1852) (Catron, J., concurring); id. at 100.01 (Daniel, J., dissenting), with Covington Drawbridge Co. v. Shepherd, 61 U.S. (20 How.) 227, 233 (1857) (Taney, J). For arguments that the reasoning of the Marshall and Letson decisions is essentially identical, see Green, supra note 18, at 219-22; McGovney, supra note 18, at 894 .

${ }^{25}$ St. Louis \& S.F. Ry. v. James, 161 U.S. 545, 562 (1896).

S. REP. No. 1830, 85th Cong., 2d Sess. (1958), reprinted in [1958] U.S. Code ConG. \& AD. News 3099, 3101.

${ }^{30} 28$ U.S.C. $\$ 1332$ (c) (1970). 


\section{B. Unincorporated Associations}

Diversity jurisdiction doctrine concerning unincorporated entities developed along different lines. In Chapman v. Barney ${ }^{31}$ the Supreme Court held that an unincorporated New York joint stock company ${ }^{32}$ could not be deemed a citizen of that state because it was not a corporation and, therefore, that federal jurisdiction could be invoked only if all the members of the company were of citizenship diverse from that of the opposing parties. ${ }^{33}$ The Court found no significance in the company's capacity to bring suit as an entity under New York law: "Although it may be authorized by the laws of the State of New York to bring suit in the name of its president, that fact alone cannot give the company power ... to sue in a federal court." 34 Chapman's formulaic reliance on the corporate/non-corporate dichotomy decided the issue in Great Southern Fire Proof Hotel Co. v. Jones, ${ }^{35}$ in which the defendant was a Pennsylvania limited partnership association..$^{36}$ The Court found that the jurisdiction of the federal courts had not been established since neither a "voluntary association" nor a non-corporate "body politic,

ง1 129 U.S. 677 (1889).

32 A joint stock company or association is a capital-pooling entity with centralized management and transferable shares like a corporation, yet whose members maintain the property rights and liabilities of partners in a general partnership. Unlike a corporation, a joint stock company is an entity formed pursuant to agreement of the parties rather than by grant of authority of its state of organization. J. Crane \& A. Bromberg, LAW OF PARTNERSHIP 17879 [hereinafter cited as Crane \& Bromberg]. The joint stock company is clearly distinguishable from the limited partnership and limited partnership association (see note 36 infra) in that both of the latter entities derive exclusively from statutes that provide limitations on the liability of some or all of the members. See generally R. ROWLEY \& D. SIVE, 2 ROWLEY ON Partnership 610-12 (2d ed. 1960) [hereinafter cited as Rowley \& Sive].

₹ 129 U.S. at 682.

3r Id. In this respect, the Court echoed the language of Chief Justice Marshall in Bank of the United States v. Deveaux, 9 U.S. (5 Cranch) 61, 85-86 (1809).

3s 177 U.S. 449 (1900).

${ }^{3}$ In a limited partnership association, the statute limits the liability of each partner to the amount of his capital subscription to the partnership. See, e.g., 59 PA. Cons. STat. $\S \S$ 341-461 (1964) (repealed in part, $1965 \mathrm{~Pa}$. Laws, Act No. 519, \& 50(g)). Unlike the limited partnership, however, the association has only one class of partner. Partners of this class have the same ownership rights in partnership property as partners in a general partnership. In its management structure and the transferability of its shares, the limited partnership association is similar to the joint stock company. See note 32 supra. See generally C. Bates, Law of Limited PARTNERship 232-49 (1886); Crane \& Bromberg, supra note 32, at 151-53. Only five states-Pennsylvania, Virginia, Michigan, New Jersey, and Ohio-have enacted statutes authorizing limited partnership associations. Virginia repealed its statute in 1918 and Pennsylvania repealed most of its statute in 1966. See statutes cited in id. at $151 \mathrm{nn} .66$ \& 68 .

The Pennsylvania statute in force at the time of Great Southern provided that limited partnership associations "shall sue and be sued in their association name." C. BATEs, supra, at 246, (quoting Act of May 1, 1876, No. 51, § 3, $1876 \mathrm{~Pa}$. Laws 89). See Great Southern Fire Proof Hotel Co. v. Jones, 177 U.S. at 455 . Individual partners could not be named as parties to a suit against the association. C. BATES, supra, at 247. 
created by law," was a "citizen." 37 Although it noted that the association was in many ways analogous to a corporation, the Court refused to extend it citizenship on the strength of that analogy. ${ }^{38}$ Diversity jurisdiction, the Court ruled, depends on "the citizenship of the several persons composing such association." 39

The Supreme Court has consistently and mechanically applied the Chapman-Great Southern rule to various forms of unincorporated associations. ${ }^{40}$ Those few decisions that have departed from the strict application of the rule have done so on the grounds that the type of association in question was qualitatively so similar to a corporation as to justify entity citizenship treatment.

In Puerto Rico $v$. Russell \& Co. ${ }^{41}$ the Court faced the question whether a sociedad en comandita, a business entity created under Puerto Rican law, is a citizen for purposes of diversity. The Court stated that although Anglo-American common law treats all unincorporated groups as partnerships, the civil law tradition of Puerto Rico was to the contrary. Noting that the rule of corporate citizenship "found its theoretical justification only in the complete legal personality with which corporations are endowed," 42 the Court found that under Puerto Rican law the sociedad had the requisite "complete legal personality." 43 In so holding, the Court focused on the fact that it was created pursuant to publicly filed articles of organization, that it had capacity to contract, own property, and litigate as an entity, that the management control might be vested solely in the firm managers, and that creditors of the firm had priority in attaching firm property over creditors of the individual members. ${ }^{44}$

In Mason v. American Express Co., ${ }^{45}$ the Second Circuit interpreted Russell as a departure from the rigidity of Chapman. The court held that a New York joint stock company (the same type of

${ }^{37} 177$ U.S. at 454 (quoting Lafayette Ins. Co. v. French, 59 U.S. (18 How.) 404, 405 (1855)).

${ }^{38} 177$ U.S. at $456-57$.

39 Id. at 456.

- $\quad$ See, e.g., Thomas v. Board of Trustees, 195 U.S. 207 (1904); Levering \& Garrigues Co. v. Morrin, 61 F.2d 115 (2d Cir. 1932), aff'd, 289 U.S. 103 (1933).

11288 U.S. 476 (1933).

12 Id. at 479 .

- Id. at 480-81. Significantly, by granting the sociedad en comandita entity citizenship, the Russell decision contracted the scope of federal jurisdiction over such entities. The Organic Act, which conferred jurisdiction on the District Court for Puerto Rico, required that one party be a non-domiciliary of Puerto Rico. 288 U.S. at 478-79, 485.

" Id. at 481. With the exception of the filing of articles of incorporation, those elements of the corporate "personality" of the sociedad are present as well in the limited partnership. See notes 68, 70 infra. See generally ROWLEY \& Sive, supra note 32, at 563-70.

${ }^{4} 334$ F.2d 392 (2d Cir. 1964). 
business entity as that involved in Chapman) should be deemed a citizen of its state of creation for diversity purposes. In an elaborate analysis, Judge Waterman traced the development of the divergent diversity rules with respect to corporations and non-corporate entities. He asserted that the Chapman Court had ignored the rationale of Marshall v. Baltimore \& Ohio Railroad"6 and had failed to consider whether other legal characteristics of a joint stock company ${ }^{47}$ would justify treating it as an entity for diversity purposes. ${ }^{48}$ The court characterized the treatment of corporate-like entities under the Chapman rule as not only illogical but patently unjust as well. ${ }^{.9}$

In seeming conflict with Mason was the decision of the Fourth Circuit in R.H. Bouligny, Inc. v. United Steelworkers of America, ${ }^{50}$ an action by a North Carolina corporation against an unincorporated labor union. The court of appeals reversed the district court's conclusion that a union was a "juridical person" equivalent to a corporation, and, citing Chapman as support, held that the union's citizenship for diversity purposes was that of its constituent members. ${ }^{51}$

The Supreme Court granted certiorari in the Bouligny case to decide "whether an unincorporated labor union is to be treated as a citizen for purposes of federal diversity jurisdiction without regard to the citizenship of its members." 52 The Court affirmed the Fourth Circuit on the basis of Chapman. Writing for a unanimous Court, Justice Fortas rejected the argument that the decision in Puerto Rico v. Russell had "breached the doctrinal wall" of Chapman. ${ }^{53}$ The issue in the Russell case, the Court explained, had been "fitting an exotic creation of the civil law . . . into a federal scheme which knew it not." 54 Although acknowledging the force of the criticisms of Chapman in Mason and in the commentary, and not explicitly disapproving Mason, the Court concluded that "these arguments, however appealing, are addressed to an inappropriate forum, [as] pleas for extension of the diversity jurisdiction to hitherto uncovered broad categories of litigants ought to be made to the Congress and

16 Id. at 395. See text and notes at notes 22-26 supra.

"See note 32 supra.

334 F.2d at $399-400$.

"Id. at 402. The commentators have also attacked the inconsistency of the Chapman decision. See, e.g., Currie, supra note 8, at 35; Comment, Diversity Jurisdiction for Unincorporated Associations, 75 YaLE L.J. 138, 143 (1965).

so 336 F.2d 160 (4th Cir. 1964), aff'd, 382 U.S. 145 (1965).

st Id. at 161-63.

52 United Steelworkers of America v. R.H. Bouligny, Inc., 382 U.S. 145, 147 (1965).

Id. at 151.

st Id. 
not to the courts." 55 Justice Fortas failed to explain why the Court, which historically had figured so prominently in the interpretation and application of the diversity jurisdiction provisions, should feel constrained to defer to the Congress on the issue of union citizenship. ${ }^{56}$ In the most convincing part of its opinion the Court emphasized a compelling practical consideration which militates against treating a union as an entity for diversity purposes. While it is a fairly easy task to fashion a rule for corporate citizenship, because all corporations have a state of incorporation and must have a principal place of business, ${ }^{57}$ there is no obvious candidate for a rule applicable to labor unions having both local and national levels of organization..$^{58}$

The scope of the holding in Bouligny is unclear, as the narrow holding of the case on the issue of the union's citizenship is overshadowed by the Court's very broad deference to Congress. One commentator, writing three years after Bouligny, noted that the implications of the decision appeared to overreach the sound reasoning upon which the case was decided. ${ }^{59}$ Still, a close reading of Bouligny suggests that the Court's language concerning the limitations of the judicial role can be restricted to the facts of the case. The Court's discussion of the difficulties of fashioning a test for labor union citizenship can be read as explaining why only Congress could extend citizenship to unions as entities. ${ }^{60}$

Because Bouligny can plausibly be read narrowly, the lower courts might have continued to follow the Mason approach to determining jurisdiction in cases involving unincorporated associations. Bouligny does not necessarily prohibit treating as "citizens" for diversity purposes those entities that have significant corporate attributes. ${ }^{61}$ Nevertheless, the cases following Bouligny have read the Court's opinion very broadly, and, with varying degrees of enthusi-

ss Id. at 150-51.

56 Professor Currie has nated the incongruity of this deference in light of the "preeminently judicial function" of applying existing statutes to unanticipated situations. Currie, supra note 8 , at 35 .

528 U.S.C. $\$ 1332$ (c) (1970).

${ }^{58} 382$ U.S. at 152-53.

${ }^{39}$ See Currie, supra note 8 , at 35.

${ }^{B 0}$ The Court specifically noted that extension of citizenship to corporations had not been substantially hindered by the problem of formulating a citizenship test. 382 U.S. at 152 .

${ }^{61}$ Indeed, the application of the Bouligny decision to all forms of unincorporated association is difficult to justify. Although Bouligny and subsequent decisions have relied on the significance of Congress' enactment of $\$ 1332$ (c), the courts arguably have the power to construe the meaning of "corporation" in that statute to include entities with significant corporate attributes. Currie, supra note 20, at 35-36; 34 GEo. WASH. L. REv. 793, 794 n.20 (1966). 
asm $^{62}$ have held that unincorporated associations may not be granted entity status for purposes of determining diversity. $.^{63} \mathrm{Al}-$ though some courts have based their holdings on the "tone and philosophy" of Bouligny, ${ }^{64}$ others have extended the "proper forum" rationale of Bouligny, and concluded that for unincorporated associations to be deemed citizens of a single state Congress would have to enact a statute analogous to 28 U.S.C. $\$ 1332$ (c), which determines the citizenship of corporations in diversity cases..$^{65}$ Although the lower courts' applications of Bouligny may go beyond the scope of that case in deferring to Congressional power to set the limits of diversity jurisdiction, it appears that the courts will continue to apply to all forms of unincorporated associations the rule that diversity depends on the citizenship of all members of the association. As a result, some types of multi-state unincorporated entities are effectively foreclosed from the diversity jurisdiction of the federal courts. ${ }^{66}$

12 Some of the opinions have made little effort to conceal their dissatisfaction with the Bouligny decision. For example, in Fox v. Prudent Resources Trust, 382 F. Supp. 81 (E.D. $\mathrm{Pa}$. 1974), Judge Luongo stated: "The reasoning of the Mason opinion is impressive. . . . Nevertheless, language in the Supreme Court's decision in [Bouligny] convinces me that I am not free to embrace the Mason approach." Id. at 92 (citation omitted).

- E.g., Baer v. United Servs. Auto. Ass'n, 503 F.2d 393 (2d Cir. 1974); Carey v. U.S. Indus., Inc., 414 F. Supp. 794 (N.D. Ill. 1976); Parish v. NCAA, 361 F. Supp. 1214 (W.D. La. 1973); Truck Ins. Exch. v. Dow Chem. Co., 331 F. Supp. 323 (W.D. Mo. 1971); George H. Draper, III, Inc. v. Canners Exch. Subscribers at Warner Inter-Ins. Bureau, 294 F. Supp. 1362 (D. Del. 1968).

" Chase Manhattan Mortgage \& Realty Trust v. Pendley, 405 F. Supp. 593, 595 (N.D. Ga. 1975).

is See, e.g., Fox v. Prudent Resources Trust, 382 F. Supp. 81, 93 (E.D. Pa. 1974).

" In some circumstances, there may be alternative ways of bringing unincorporated associations into federal courts. An unincorporated association may sue or be sued in one of three ways: (1) as an entity under an applicable state common name statute; (2) as an aggregate of individuals, either by joinder of all members, where they are jointly liable, or individually, where the members are severally liable; and (3) as a class, by designating one or more members of the association as representative of the class composed of all the members. 9A C. Wright \& A. Mirler, Federal Practice and Procedure 451-53 (1972). Even after rejection of an "entity" approach to diversity jurisdiction over unincorporated associations the latter two alternatives may result in diversity depending on the citizenship of the individuals selected. Suing only some members who are severally liable, however, may result in incomplete recovery.

Courts and commentators have recognized the class action as a means of circumventing the harsh result of Chapman and Bouligny since where a representative sues or is sued on behalf of a class composed of an unincorporated association's members; only the citizenship of the representative is relevant to diversity. Supreme Tribe of Ben-Hur v. Cauble, 255 U.S. 356 (1921). See, e.g., Mason v. American Express Co., 334 F.2d 392, 402 (2d Cir. 1964); 51 CoRNeLL L.Q. 827, 831-32 (1966). But several commentators have found offensive the scope of discretion plaintiffs have in choosing a federal forum through careful selection of a representative party, even when most members of the association may be non-diverse. See Comment, Citizenship of Unincorporated Associations for Diversity Purposes, 50 VA. L. REv. 1135, 


\section{Determining Diversity for Limited Partnerships: Two Rules}

Limited partnerships are creatures of statutory law, ${ }^{67}$ now treated with a high degree of uniformity under the Uniform Limited Partnership Act, which has been adopted, with only minor deviations, throughout the United States. ${ }^{68}$ Although the limited partner-

1142 (1964); Comment, Diversity Jurisdiction for Unincorporated Associations, 75 YALE L.J. 138, 143-44 (1965).

The class action alternative became more complex with the enactment in 1966 of Federal Rule 23.2. It provides especially for class actions by or against unincorporated associations but leaves two issues unresolved. The first issue is whether an action may be maintained under rule 23.2 without satisfying the prerequisites of rule $23(\mathrm{a})$. The commentary suggests that it may be. E.g., 3B Moore's Federal Practice If 23.2.02, at 23.2-7 (1977). This conclusion rests largely on the fact that rule 23.2 expressly incorporates the provisions of rules 23 (d) and $23(\mathrm{e})$ in the text while omitting the provisions of rule 23(a). Id. Several recent district court decisions, however, have taken the opposite view. E.g., Suchem, Inc. v. Central Aguirre Sugar Co., 52 F.R.D. 348, 355 (D.P.R. 1971). See 9A C. WRIGHT \& A. MrLleR, supra, at 457-58. The inapplicability of rule 23(a) would produce some rather anomalous results. For example, without the numerosity requirement, a diversity action could conceivably be maintained against a two-man partnership by naming the diverse party as class representative.

The second question is whether a rule 23.2 action can be brought when applicable state law either (1) prohibits class actions by or against unincorporated associations (by providing for exclusive forms of remedy), or (2) provides permissive alternative methods for such associations to sue or be sued (for example, the common name statutes of most states). The first issue arose prior to the 1966 amendment as well. The Third Circuit, in Underwood v. Maloney, 256 F.2d 334 (3d Cir. 1958), cert. denied, 358 U.S. 864 (1958), held that the Pennsylvania common name statute was exclusive and suit could not be brought against an individual as representative of a class of association members. Where a state's common name statute was not exclusive, though, the First Circuit held that a class action was maintainable. Oskoian v. Canuel, 269 F.2d 311 (1st Cir. 1959). In Suchem, Inc. v. Central Aguirre Sugar Co., 52 F.R.D. 348, 355 (D.P.R. 1971), however, the district court read rule 23.2 as applicable only when state law provides no mechanism for an unincorporated association to sue or be sued as an entity. Accord, Lee v. Navarro Sav. Ass'n, 416 F. Supp. 1186 (N.D. Tex. 1976). But see Pyle v. Arthur Anderson \& Co., 16 Fed. Rules Serv. 2D 634 (D. Ore. 1974). The Advisory Committee Note on rule 23.2 states that the main purpose of the rule is "to give "entity treatment' to [an] association when for formal reasons it cannot sue or be sued as a jural person," which may suggest that the Suchem interpretation is correct. FED. R. Civ. P. 23.2, Advisory Committee Notes, 39 F.R.D. 69, 108 (1967). But at least one commentator reads this language as supporting the view that rule 23.2 is supplementary to, and not in conflict with, existing state provisions, and that even if a conflict exists the Federal Rules should govern. 9A C. WRIGHT \& A. MILLER, supra, at 459. If permissive common name statutes are ultimately held to preclude actions under rule 23.2 , then the class action in most cases will offer no relief from the Chapman-Bouligny rule.

67 The first state limited partnership act was adopted in New York in 1822. An Act Relative to Partnership, ch. 244, $\S 1,1822$ N.Y. Laws 259. The New York act was patterned after the "societe en commandite" under the French Commercial Code. C. BATES, LAW of Limted Partnership 20-21 (1886); see Comment, The Limited Partnership, 45 Yale L.J. 895, 895-96 (1936).

4 UNIFORM LimtTed PaRTNERship ACT $\$$ 1-31 (1916) [hereinafter cited without cross reference as U.L.P.A.]. See generally REvised UNIFORM LIMITED PARTNERSHIP Act $\S \S 101-1105$ (1976). The U.L.P.A. was drafted in 1916 to remedy failures of various state acts to protect the "limited partners" from potentially unlimited liability. U.L.P.A. § 1, Official Comment. Only Louisiana, with its unique partnership in cammendam, has not adopted the U.L.P.A. 
ship was initially an investment device utilized by small groups of investors for intrastate transactions, ${ }^{69}$ it has today become a popular method of obtaining capital for all forms of business venture. ${ }^{70}$

Under the Chapman-Bouligny line of cases limited partnerships cannot be accorded entity citizenship for diversity purposes, even though they have many significant corporate-like attributes. ${ }^{11}$ A literal application of the rule first announced in Great Southern Fire Proof Hotel $v$. Jones, ${ }^{72}$ that in diversity cases involving a "partnership association" the court will look to the citizenship of "the several persons composing such association," "73 would demand that the courts look to the citizenship of both the general and limited partners in testing for diversity of citizenship. In two recent cases the Second and Third Circuits reached different conclusions about the significance for diversity purposes of the two-level structure of the limited partnership, ${ }^{74}$ and consequently disagreed over whether the citizenship of limited partners counts for jurisdictional purposes.

\section{A. Colonial Realty and Carlsberg Resources}

Colonial Realty Corp. $v$. Bache \& $\mathrm{Co}^{75}$ was the first diversity

Although some states, in enacting their limited partnership statutes, have made some changes from the language of the U.L.P.A., most are insignificant for purposes of the discussion herein. Those changes that are relevant will be noted where appropriate. See generally The National Conference of Commissioners on Uniform State Laws, 6 Uniform Laws ANNOTATED (1969) [hereinafter cited without cross reference as UNIFORM LAWs ANNOTATED]. The dates of enactment and corresponding statutory citations for those jurisdictions that have adopted the U.L.P.A. are listed at 6 Uniform Laws ANNotated 83 (Supp. 1977).

- Comment, Foreign Limited Partnerships: A Proposed Amendment to the Uniform Limited Partnership Act, 47 S. CAL. L. REv. 1174, 1176-77 (1974).

${ }^{70}$ A typical limited partnership today will involve hundreds of investors, generally from several states, as limited partners and will engage in multistate business transactions. These large partnerships can be characterized as "public limited partnerships" because they are offered as investments to the public, often through S.E.C.-registered prospectuses. See Hrusoff \& Cazares, Formation of the Public Limited Partnership, 22 HAsTings L.J. 87 (1970).

"F For example, a limited partnership can exist only where authorized by state statute or recognized by comity. The limited liability of the limited partners, U.L.P.A. $\S \S 1,7$, is like that of corporate shareholders and the business of the partnership is conducted by the general partners, U.L.P.A. $\$ 9$, in much the same way as corporate business is managed by the board of directors. See RowLEY \& Sive, supra note 32, at 549.

72177 U.S. 449 (1900).

73 Id. at 456.

7 Limited partnerships, by definition, have two classes of members: "A limited partnership is a partnership formed by two or more persons . . . having as members one or more general partners and one or more limited partners." U.L.P.A. $\$ 1$. The requirement of at least one member with general liability and one with limited liability distinguishes limited partnerships from joint stock companies, general partnerships, and limited partnership associations.

${ }^{75} 358$ F.2d 178 (2d Cir.), cert. denied, 385 U.S. 817 (1966). 
case involving a limited partnership to reach a court of appeals. ${ }^{76}$ In an opinion delivered by Judge Friendly, the court, although acknowledging the Great Southern rule, ${ }^{77}$ held that only the citizenship of the general partners of a New York limited partnership was relevant to determining diversity. Because a limited partner, under the applicable New York statute, was not a proper party to a suit against a partnership unless the action sought to enforce his rights against or liability to the partnership, ${ }^{78}$ Judge Friendly reasoned that such a partner should not be considered a "person composing" the partnership for diversity purposes. Several courts have followed the Colonial Realty rule in limited partnership cases, ${ }^{79}$ and the rule appears to be settled law in the Second Circuit. ${ }^{80}$

The Court of Appeals for the Third Circuit recently rejected the Colonial Realty rule in the case of Carlsberg Resources Corp. $v$. Cambria Savings \& Loan Association. ${ }^{81}$ The defendant was a Pennsylvania corporation and the named plaintiff, a California corporation, was the sole general partner of the plaintiff limited partnership, some of whose limited partners were citizens of Pennsylvania. Because plaintiffs failed to aver that all the limited partners were of citizenship diverse from the defendants, the district court dismissed the case in reliance on the Chapman-Bouligny line of authority. ${ }^{82}$ On appeal, the Third Circuit recognized that plaintiff's theory was not that the entity was a citizen for diversity purposes, but that the citizenship of the general partners only was determinative. The court framed the issue as "whether parties of divergent status may be treated differently for "purposes of an.evaluation regarding diversity jurisdiction." 83

7 It is not entirely surprising that it was almost 150 years after the first limited partnership statute that this issue was first litigated at the appellate level, since limited partnerships were apparently not widely used as large-scale investment enterprises until after World War II. See Crane \& Bromberg, supra note 32, at 150.

${ }^{77} 358$ F.2d at 183. "[C]itizenship of a limited partnership [is] not sufficiently made out for diversity purposes by alleging the state of its organization . . . ."

${ }^{78}$ Id. at $183-84$.

79 See, e.g., C.P. Robinson Constr. Co. v. National Corp. for Hous. Partnership, 375 F. Supp. 446 (M.D.N.C. 1974); Sands v. Geller, 321 F. Supp. 1107 (S.D.N.Y. 1970).

so See, e.g., Woodward v. D.H. Overmyer Co., 428 F.2d 880, 883 (2d Cir. 1970) (dictum); Erving v. Virginia Squires Basketball Club, 349 F. Supp. 709 (E.D.N.Y. 1972). Cf. Lewis v. Odell, 503 F.2d 445 (2d Cir. 1974) (general partnership case stating that "for purposes of diversity a partnership is a citizen of each state of which a general partner is a citizen," id. at 446); Boise Cascade Corp. v. Wheeler, 419 F. Supp. 98 (S.D.N.Y. 1976) (general partnership case citing Lewis as controlling).

${ }^{81} 554$ F.2d 1254 (3d Cir. 1977).

27 Carlsberg Resources Corp. v. Cambria Sav. \& Loan Ass'n, 413 F. Supp. 880 (W.D. Pa. 1976). The court considered the jurisdictional question sua sponte.

554 F.2d at 1259. 
Judge Adams, writing for the majority, set forth two distinct threads of analysis. ${ }^{84}$ The court first analyzed the issue in terms of the "interplay" between the complete diversity requirement of Strawbridge $v$. Curtiss ${ }^{85}$ and the treatment of unincorporated associations in Chapman, Great Southern, and Bouligny. Although recognizing that those precedents "do not squarely address the exact question posed" in this case, ${ }^{86}$ the majority relied on inferences that it believed could reasonably be drawn from the treatment in those decisions of associations with more than one class of members. The majority read Chapman ${ }^{87}$ as involving an association with two classes of member: the president, who had the capacity to sue, and all other shareholders in the joint stock company. In the Supreme Court's holding that all the members' citizenship was relevant "[d]espite such class distinctions," the majority found implicit "a refusal . . . to differentiate between classes of association or partnership members regarding questions of diversity." 88 Because the association members in Great Southern were of a single class, the majority could only conjecture that the requirement of looking to all members of the association "may well apply" to the limited partnership as well. ${ }^{89}$ On its reading of Chapman and Great Southern, the court necessarily viewed the Colonial Realty decision as creating an "exception" from the general rule for unincorporated associations and from the "traditional treatment of partnerships." the "hard line"91 which the Bouligny Court had taken against expansion of diversity jurisdiction, the court could not countenance the Colonial Realty "exception."

The court had reasons apart from the implications of Supreme Court precedent for rejecting the Colonial Realty approach. It found the Second Circuit's capacity-to-sue rationale to be problematic in several respects. First, the court was disturbed by the apparent anomaly of considering capacity to sue before determining the jurisdictional issue. Second, the court thought it persuasive against the

s The court prefaced its analysis of the issue with a discussion of the policy considerations that the court said would "serve to frame our inquiry." Id. at 1257. The two factors relied on by the majority were: (1) the "additional burdens" that would be imposed on an already overtaxed federal court system, id. at 1256, and (2) the violation of the "cardinal precepts" of federalism engendered by an expansion of federal jurisdiction into areas traditionally within the responsibility of state courts. Id. at 1257.

ss 7 U.S. (3 Cranch) 267 (1806).

4 554 F.2d at 1259.

5ee text and notes at notes 31-34 supra.

s54 F.2d at 1259.

Id. at 1258 .

- Id. at 1262 .

"Id. at 1259. 
capacity test that the test would "empower state legislators or state courts to determine the perimeters of federal jurisdiction," and thus make diversity jurisdiction "dependent on the vagaries of state law."92 Finally, the test appeared to the court to violate the command of rule 82 of the Federal Rules of Civil Procedure that the Federal Rules not be construed to expand the jurisdiction of the federal courts. ${ }^{93}$ Assuming that Colonial Realty relied on rule 17(b) as authority for applying the state capacity rules for diversity purposes, ${ }^{94}$ the court thought that such reliance ran afoul of rule 82 by operating to "liberalize access to the federal courts." that the capacity of limited partners to sue is "deserving of consideration only after the jurisdiction of the federal court has been firmly established." 96

Judge Hunter, in dissent, disagreed with both lines of reasoning followed by the majority. He first found that established jurisdictional rules for unincorporated associations did not govern because the Supreme Court had never considered diversity jurisdiction for an entity similar to a modern limited partnership. In finding the Colonial Realty position to be a corollary rather than an exception to the rule for general partnerships, the dissent focused on the unique character of the membership of a limited partnership and concluded that the Strawbridge requirement of diversity of citizenship of all parties representing the "distinct interests" in an action required the court to determine first just who these parties are. ${ }^{97} \mathrm{In}$ the case of partnerships, Judge Hunter found that the court must look to "the state law that shapes them." "98 Noting the provisions of the U.L.P.A. that protect limited partners from unlimited liability, curtail their role in management of the partnership, and preclude their participation in suits involving the partnership, ${ }^{99}$ Judge

${ }^{82}$ Id. at 1261.

25 FED. R. Crv. P. 82 provides that "the Federal Rules shall not be construed to extend or limit the jurisdiction of the United States district courts."

"FED. R. Crv. P. 17(b) provides in pertinent part that "[t]he capacity of an individual, other than one acting in a representative capacity, to sue or be sued shall be determined by the law of his domicile."

${ }_{95} 554$ F.2d at 1261.

* Id. at 1260 .

nId. at 1263-64.

8s Id. at 1264.

"Section 7 of the U.L.P.A. provides that "[a] limited partner shall not become liable as a general partner unless, in addition to the exercise of his rights and powers as a limited partner, he takes part in the control of the business." Compare U.L.P.A. $§ 10$, which sets forth the rights of limited partners. Section 26 of the U.L.P.A. provides that "[a] contributor, unless he is a general partner, is not a proper party to proceedings by or against a partnership, except where the object is to enforce a limited partner's right against or liability to the partnership." 
Hunter observed that "the majority would have us take cognizance, for diversity purposes, of persons who, under state law, are clearly prohibited from taking part in a suit by or against the partnership. This, to me, appeals neither to logic nor to common sense."100

The majority was incorrect in concluding that the Colonial Realty rule is foreclosed by the Supreme Court precedents. As noted by the dissent, Chapman, Great Southern, and Bouligny held only that unincorporated associations cannot be granted entity citizenship for jurisdictional purposes. Moreover, the majority's reliance on Great Southern and Chapman goes well beyond the facts of those cases. There is nothing in Great Southern to support the majority's supposition that the case implicitly rejected any jurisdictional distinction based on the character of separate classes of membership. ${ }^{101}$ The majority's deduction from Chapman that all association members must be counted for diversity purposes, regardless of capacity to sue, would be convincing only if the joint stock company in Chapman had in fact been composed of more than one class of member. The fact that the president in that case could function as the named party in an action involving the company, however, did not reflect any difference in substantive or procedural rights and liabilities. ${ }^{102}$ Thus, the Supreme Court in Chapman and Great Southern did not explicitly refuse to distinguish between classes of members for diversity purposes, nor is the silence of those cases on that point evidence that the Court disapproved such an approach. Judge Hunter in dissent more accurately concluded that " $[t]$ he Supreme Court has not even touched on the topic." 103 Its questionable reading of Supreme Court authority led the majority to treat Colonial Realty as a departure from a "general" rule for unincorporated associations, and thus as contrary to Bouligny's interdiction of judicial enlargement of the diversity jurisdiction.

Although Colonial Realty is not, as the Carlsberg majority thought, plainly contrary to specific Supreme Court precedents, the question remains whether it is more consistent with diversity jurisdiction policies and precedent than is Carlsberg Resources. Prima facie, the Third Circuit has the better of it: the Carlsberg rule seems a reasonable application of the Great Southern "persons compos-

${ }^{100} 554$ F.2d at 1265.

101 See note 36 supra.

${ }_{102}$ The provision in Chapman for suit in the name of the president was permissive only and did not act in derogation of a party's right to sue all members of the company as general partners. N.Y. Code of Civil Procedure \$ 1919 (1883). See Rowley \& Sive, supra note 32, at 625 . But see note 66 supra. Each member's personal assets stood behind the debts of the company. See note 32 supra.

${ }^{103} 554$ F.2d at 1264. 
ing" test, for it is undeniable that limited partners are "persons composing" the limited partnership, even though they lack capacity to sue. The brief discussion of the jurisdictional issue in Colonial Realty did not spell out the relationship between capacity-to-sue rules and the law of diversity jurisdiction. Although the Carlsberg majority is correct in saying that the capacity of an entity to sue does not confer citizenship for diversity purposes, ${ }^{104}$ it does not follow that a limited partner's incapacity to sue is irrelevant to whether his citizenship counts for diversity purposes. ${ }^{105}$ In order to determine whether Carlsberg states the rule that is more consistent with diversity doctrine, it is necessary to inquire more closely into the alternatives suggested by Colonial Realty.

\section{B. Analysis of Colonial Realty}

1. The Capacity-to-Sue Approach. Both Colonial Realty and the Carlsberg Resources dissent appear superficially to have analyzed the issue in terms of the procedural capacities of the partners. Under this view, limited partners are acknowledged as persons composing the partnership, but only those partners who have capacity to sue or be sued on behalf of the partnership under applicable state law are counted for diversity purposes. ${ }^{106}$ The approach of resting federal jurisdiction on capacity to sue has been used in other contexts. ${ }^{107}$ In Mexican Central Railway Co. v. Eckman, ${ }^{108}$ the Supreme

${ }^{10}$ Indeed, this was the substance of the holdings in Chapman and Great Southern.

${ }_{105}$ The distinction between allowing capacity to sue to confer entity citizenship, on the one hand, and the effect that capacity to sue might have on the relevance to diversity jurisdiction of a class of members, on the other, was not acknowledged by the majority, which observed that the "Supreme Court has . . . declined to view problems involving diversity jurisdiction through the perspective of capacity to sue." 554 F.2d at $1260 \&$ n.24. This failure is noted by Judge Hunter in his dissent. Id. at 1263 n.5.

${ }^{106}$ In his dissent in Carlsberg Resources Judge Hunter noted that, although capacity to sue and diversity jurisdiction were separate issues, "capacity to sue-as dictated by state law-generally selects the proper parties, for diversity purposes." 554 F.2d at 1263 n.6.

${ }_{107}$ See, e.g., Chappedelaine v. Dechenaux, 8 U.S. (4 Cranch) 306, 307 (1808); Osborn v. Bank of the United States, 22 U.S. (9 Wheat.) 738, 856-57 (1824). The general principle that the citizenship of the named party is looked to in determining diversity when a party has the right to sue or be sued on behalf of others is subject to the limitation that where the named party is a mere "conduit" the citizenship of the persons whose rights and liabilities are being enforced will determine diversity. This exception, acknowledged by the Supreme Court in Coal Co. v. Blatchford, 78 U.S. 172, 177 (1870), is summarized in 13 C. Wright \& A. Miller, Federal Practice and Procedure 629-30 (1975):

[T] he representative must have actual powers with regard to the matter in litigation. Accordingly, when the representative cannot prevent the institution or prosecution of the actions, or exercise any control over them, and is a mere conduit through whom the law affords a remedy to persons aggrieved, the representative party is treated as a nominal party, and the citizenship of those who are being represented is determinative. [footnote omitted].

${ }^{108} 187$ U.S. 429 (1903). 
Court held that the citizenship of a guardian, rather than that of the minor he represented, was determinative if the guardian had capacity to sue in his own name. ${ }^{109}$ More recently, the Third Circuit followed Eckman in Fallat $v$. Gouran, ${ }^{110}$ another guardianship case. The Fallat court described the capacity-to-sue approach as a means of "defining" the jurisdictional requirement." ance on rule 17 capacity-to-sue provisions as merely definitional, the court saw no violation of the limitation imposed by rule $82 .{ }^{112}$

Eckman and Fallat demonstrate that, the Carlsberg majority's objections notwithstanding, ${ }^{113}$ rule $17(\mathrm{~b})$ often makes federal jurisdiction turn on the "vagaries of state law." If, for example, state law permits a general partnership to sue or be sued as an entity, but not as a class, the lack of diversity between one partner and an opposing party destroys diversity. But if state law permits suits by or against the partnership as a class, rule 17 (b) allows the action to proceed as a class action, and diversity jurisdiction can be invoked by naming a class representative of citizenship diverse to the opposing parties. ${ }^{114}$

Although some precedent supports the use of capacity to sue as a limitation on the Great Southern "persons composing" test, reliance on capacity to sue alone is unsatisfactory as a general jurisdictional principle. Entities treated one way under unquestioned precedents would be treated differently under a strict capacity-to-sue test. In Chapman, for example, the joint stock company was empowered to sue only in the name of its president or treasurer. ${ }^{115}$ Rote application of the capacity-to-sue rule would indicate, contrary to the Supreme Court's decision, that only the named officer's citizenship was relevant for diversity purposes. In order to reach the Supreme Court's conclusion that the citizenship of all the parties represented (all the members of the company) rather than that of the representative only (the president of the company) is relevant to diversity, a court would have to apply an analogue to the "conduit"

109 Id. at 433-34 ("The question is whether under the laws of Texas a guardian can sue in his own name . ....").

110220 F.2d 325 (3d Cir. 1955). The majority opinion in Carlsberg Resources did not cite either Eckman or Fallat, although it did note, at 554 F.2d 1260 n.24, the case of McSparran v. Weist, 402 F.2d 867 (3d Cir.), cert. denied, 395 U.S. 903 (1968), that recognized the rule stated in Fallat but created an exception for collusive appointment of an out-of-state guardian for the sole purpose of creating federal jurisdiction.

iI 220 F.2d at 328.

112 Id. at $327-28$.

${ }^{113}$ See text at note 92 supra.

11 See Comment, The Problem of Capacity in Union Suits: A Potpourri of Erie, Diversity, and the Federal Rules of Civil Procedure, 68 YALE L.J. 1182, 1185 (1959).

${ }^{115}$ See text and note at note 102 supra. 
exception applied in representative actions. In representative suits the courts will look beyond the representative to the citizenship of the persons represented if the latter exercise so much control over the representative that he is a mere "conduit" for the enforcement of their rights. ${ }^{116}$ The representative in Chapman could be viewed as a "conduit" for all the other members since he had no greater rights or liabilities than the others and was powerless to prevent institution of the suit. Thus a naked capacity-to-sue test is unsatisfactorily narrow. An approach based on capacity to sue can be squared with the precedents only if it is supplemented by an "exception" designed to take account of the citizenship of controlling persons who lack capacity to sue. ${ }^{117}$

2. The "Real Party" Approach. Although Judge Friendly in Colonial Realty and Judge Hunter in his Carlsberg Resources dissent seemed to emphasize the importance of general partners' capacity to sue, this does not necessarily imply that capacity is determinative. Judge Hunter clearly embraced a broader view. He would look to "those who have the capacity to bring suit, and in some cases where the categories diverge, those who are the real parties in interest." 118 Under Judge Hunter's approach capacity to sue is not important intrinsically, but is relevant only insofar as it reflects certain facts about the relative rights and liabilities of the persons composing the association. He explained how his "real party" concept applies to cases involving general partnerships:

"16 See note 107 supra.

117 An additional difficulty with a bare capacity-to-sue test involves the choice of law in determining that capacity. Choice of law under this approach might appear to be governed by rule 17(b) of the Federal Rules of Civil Procedure, which provides in relevant part:

The capacity of an individual, other than one acting in a representative capacity, to sue or be sued shall be determined by the law of his domicile. . . . In all other cases capacity to sue or be sued shall be determined by the law of the state in which the district court is held .....

On its face, the rule seems to demand reference to the domicile of each limited partner. However, the law of a limited partner's domicile should be irrelevant to the jurisdictional question since that same law is unlikely to apply to the substantive issues concerning the rights and liabilities of the limited partners. The alternative provision of rule $17(\mathrm{~b})$ might be invoked on the theory that consideration of an individual's capacity to sue to determine jurisdiction over an entity, rather than over that individual, is within the scope of the "other cases" contemplated by the rule. The majority in Carlsberg Resources assumed without explanation that this latter portion of rule $17(\mathrm{~b})$ would govern and therefore that forum state law would apply. 554 F.2d at 1261 \& n.26.

The incongruity of automatically applying the law of the limited partner's domicile or the law of a possibly disinterested forum to determine diversity jurisdiction over a limited partnership reinforces the conclusion that the limited partner's participation in controlling the enterprise, rather than his capacity to sue, ought to determine the relevance of his citizenship to the issue of diversity jurisdiction.

118554 F.2d at 1263. 
In a general partnership, each partner is jointly and equally responsible for the organization's affairs. Each can sue on behalf of the partnership. Thus when a general partnership brings suit in federal court, alleging diversity jurisdiction, the court turns to state law and determines that . . . each must be "counted" for diversity purposes. ${ }^{119}$

Judge Hunter's view of the basis of the partnership diversity rule finds no explicit support in the Supreme Court's opinion in Great Southern, but it is certainly a cogent explanation of the rule of that case. It is not entirely surprising that the Court in Great Southern gave no reason for looking to the citizenship of all the partners; once the Court had concluded that the limited partnership association was not a "citizen" for diversity purposes, the only alternative was to look to all its constituent members. ${ }^{120}$ The limited partnership association had but one class of members, all of whom had full management rights and obligations, and all of whom enjoyed limited liability. ${ }^{121}$ The Great Southern rule also makes sense in suits by or against general partnerships, because both the common law and the Uniform Partnership Act regard general partnerships as joint enterprises. The partners jointly run the business, ${ }^{122}$ all have management rights in the business, ${ }^{123}$ and all are personally liable for partnership obligations. ${ }^{124}$ An action by or against a general partnership under a common name statute is an action to enforce the cumulative rights or obligations of all the partners.

When we turn to the case of limited partnerships and examine the "state law that shapes them," the justification for looking to the citizenship of all the partners is not so apparent. As Judge Hunter noted in his dissent, limited partners are a "distinct breed." 125 The Official Comments to section 1 of the Uniform Limited Partnership Act point out that a limited partner "is not in any sense a part-

11 Id.

120 To have eliminated all the partners from consideration would have left the partnership with no citizenship for diversity purposes.

${ }^{121}$ See note 36 supra.

122 A partner's interest in partnership was regarded at common law as a modified form of tenancy in common. See Crane \& Bromberg, supra note 32, at 228; Campbell, Partnership Obligations and Their Enforcement, 32 Chi.-Kent L. Rev. 127 (1954). Uniform Partnership ACT [hereinafter cited without cross-reference as U.P.A.] § 25 (1914) similarly describes partners' property rights.

${ }^{123}$ U.P.A. $\$ 18(\mathrm{e})$. For the common law rule see, for example, Bengston v. Shain, 42 Wash. 2d 404, 255 P.2d 892 (1953).

${ }^{124}$ U.P.A. \$ 15. For the common law rule see C. Bates, Law of Partnership 477 \& n.5 (1888).

${ }^{125}$ Carlsberg Resources Corp. v. Cambria Sav. \& Loan Ass'n, 554 F.2d at 1265. 
ner."126 His rights with respect to management of the partnership are very narrow and do not include the right to bind the partnership in contract, the right to dispose of partnership property, or the right to vote in matters concerning the business of the partnership. ${ }^{127} \mathrm{~A}$ limited partner, while entitled to his distributive share of the partnership profits, does not have an interest in the property of the partnership ${ }^{128}$ nor can he cause dissolution of the partnership except by judicial decree. ${ }^{129}$ Because of these restrictions, a limited partner is not liable to third persons for the debts or torts of the partnership $^{130}$ and cannot sue or be sued on behalf of the partnership. ${ }^{131}$ Unlike a general partner or a member of a joint stock company, a limited partner is not an agent of the association or of the individual members. ${ }^{132} \mathrm{He}$ can best be characterized as a "mere contributor of capital." 133 Thus in most cases limited partners cannot realistically be deemed parties to actions by or against the partnership.

The "real party" approach advocated by Judge Hunter is virtually identical to the supplemented capacity-to-sue approach discussed earlier. ${ }^{134}$ Both tests focus on the element of control. A court applying either test would not look to the citizenship of a limited partner unless the partner had assumed such powers of management that he could be deemed a party in fact.

\section{Evaluation of the Competing Rules}

The lower court cases thus reveal two distinct approaches to determining diversity jurisdiction in suits involving limited partnerships. The first of these-the approach of the majority in Carlsberg

1266 UNIFORM LAWS ANNOTATED 564 (1969).

127 U.L.P.A. \$\$ 4, 7, 9, \& 10; see Crane \& Bromberg, supra note 32, at 273 n.2. Cf. CaL. CORP. CODE $\$ 15507$ (West 1977) (permitting limited partners to exercise certain voting rights without losing limitation on liability).

12s Compare U.L.P.A. $\$ \$ 10$ and 18 with U.P.A. $\$ 25$.

129 Compare U.P.A. $\$ \$ 29$ and 31 (dissolution of partnership when any partner severs relationship with partnership) with U.L.P.A. \$10. See CRANE \& BROMBERG, supra note 32, at 517.

${ }^{130}$ U.L.P.A. $\$ \S 7,9$. See U.P.A. § 15.

131 U.L.P.A. $\$ 26$ provides: "A contributor, unless he is a general partner, is not a proper party to proceedings by or against a partnership, except where the object is to enforce a limited partner's right against or liability to the partnership." But see Note, Standing of Limited Partners to Sue Derivatively, 65 Colum. L. Rev. 1463 (1965).

${ }_{132}$ Lynn v. Cohen, 359 F. Supp. 565, 567-68 (S.D.N.Y. 1973). See U.P.A. § 9(1).

133 Alley v. Clark, 71 F. Supp. 521, 527 (E.D.N.Y. 1947) (limited partners have no proprietary interest in partnership, merely a creditor's interest); cf. Estate of Meyer v. Commissioner, 503 F.2d 556 (9th Cir. 1974) (exchange of limited partnership interest for general partnership interest is not a "like-kind" exchange because limited partner does not have general partner's broad spectrum of rights and liabilities).

${ }^{134}$ See text and notes at notes 115-117 supra. 
Resources-is consistent with the broad literal reading of Chapman and Great Southern. The second approach-the "real parties" rule articulated by Judge Hunter-is reconcilable with the narrow holding of those cases. Further analysis reveals, however, that the latter approach is more consistent both with the corpus of diversity precedents and with the policy underlying the statute.

\section{A. Judicial Doctrine}

The Carlsberg court rested its decision on what it viewed as the established rule for all unincorporated associations. That rule-that the court must look to the citizenship of all the members of the association-contrasts sharply with the Marshall rule for corporate entities. It is commonly thought that the unincorporated association rule can be assimilated to Marshall on the ground that although the Court's decision had the effect of treating the corporation as a citizen, the Court nevertheless regarded the shareholders' citizenship as relevant to diversity. "[T] Bouligny, "indulged in the fiction that, although the corporation was not itself a citizen for diversity purposes, its shareholders would conclusively be presumed citizens of the incorporating State." 135

The Court in Marshall did state its presumption of citizenship in terms of the "persons" who act under the corporate "faculties." "136 A close reading of Justice Grier's opinion suggests, however, that the presumption extended not to the shareholders but to the representatives of the shareholders-the directors-who were the "real parties" to the suit. ${ }^{137}$ Thus the presumption of citizenship (which had

135 United Steelworkers of America v. R.H. Bouligny, Inc., 382 U.S. 145, 148 (1965). This is the traditional reading of Marshall. See, e.g., Mason v. American Express Co., 334 F.2d 392, 394 (2d Cir. 1964); C. Wright, HaNdBook of the LAW of Federal Courts 101 (3d ed. 1976); Moore \& Weckstein, Corporations and Diversity of Citizenship Jurisdiction: A Supreme Court Fiction Revisited, 77 HARv. L. REv. 1426, 1428 (1964). Indeed, there has been little reason to question this reading of the case since the effect of the presumption-treating a corporation as a citizen of its incorporation state-made it irrelevant to whom the presumption applied.

134 Marshall v. Baltimore \& Ohio R.R., 57 U.S. (16 How.) 314, 328 (1853).

${ }_{137}$ The key sentence of the opinion is frustratingly ambiguous. The Court was unclear as to the referents of the presumption regarding those "persons who act under [the corporate] faculties." Earlier in the opinion the Court noted that shareholders have the "faculties" of acting through their elected representatives in their collective corporate name. 57 U.S. at 327. Later, though, the Court stated that an averment of the state of creation of a corporation was sufficient for jurisdictional purposes because of the presumption with respect to those exercising the corporate "faculties," the "real defendants" in the suit; these "real defendants," or "real parties to the controversy" were recognized by the Court as being not the shareholders, but their representatives. Id. at 328-29; see Green, Corporations as Persons, Citizens and Possessors of Liberty, 94 U. PA. L. Rev. 202, 213 (1946). As an example of the need for the presumption of citizenship, the Court noted that without it a corporation could 
the effect of treating the corporation as a citizen) followed the initial determination to regard only "real parties" as relevant for diversity purposes.

Marshall can be viewed as part of a broader spectrum of contemporaneous decisions that held that the relevant citizenship for diversity purposes in suits brought by a person in the beneficial interest of another was that of the representative, the "real party." 138 In Bonnafee $v$. Williams, ${ }^{139}$ which decided the jurisdictional status of the trustee and beneficiaries of a trust, the Court held that " $[w]$ here . . . the legal right to sue is in the plaintiff, the court will not inquire into the residence of those who may have an equitable interest in the claim." 140 The relationship between the trustee and beneficiaries in Bonnafee is analogous to the relationship between directors and shareholders, as the Marshall opinion acknowledged:

[T] he court in deciding the question of jurisdiction, will look behind the corporate or collective name given to the party, to find the persons who act as the representatives, curators or trustees, of the association, stockholders or cestuis que trust, and in such capacity are the real parties to the controversy. .... . ${ }^{41}$

This same trust analogy was invoked in the 1832 decision of the New York Court of Chancery, which first recognized a shareholder deriv-

defeat jurisdiction "by electing a single director residing in a different state." Id. at 328 (emphasis added).

Additional support for this reading of the case can be drawn from the dissenting opinions. Justice Catron, whose opinion was summarized by the Court reporter, apparently objected only to the holding that the requisite citizenship of the corporate officers and directors need not be averred to maintain jurisdiction. 57 U.S. at 337. Indeed, in his concurrence in Rundle v. Delaware \& Raritan Canal Co., 55 U.S. (14 How.) 80 (1852), Justice Catron had stated: "If the president and directors [of a corporation] are citizens of the State where the corporation was created, and the other party to the suit is a citizen of a different State . . . then the courts of the United States can exercise jurisdiction under the third article of the Constitution." Id. at 94. Justice Daniel's dissent in Marshall, which reiterated that the parties to the suit must be citizens and that these citizens must meet the statutory diversity requirements, argued that the majority's rule failed to satisfy both requirements. 57 U.S. at 339-41. The position which he attacked was not that the shareholders could be presumed citizens of the state of incorporation, but "that a corporation, created by a state, can have no being or faculties beyond the limits of that state; and if its president and officers reside within that state, such a conjuncture will meet and satisfy the predicament laid down by the Constitution." Id. at 338. That the citizenship of these parties need not be averred he regarded as a double perversion of the Constitution.

13* See McNutt v. Bland, 43 U.S. (2 How.) 9, 15 (1844).

130 44 U.S. (3 How.) 573 (1845).

${ }^{140} \mathrm{Id}$. at 577.

$1+57$ U.S. at $328-29$. 
ative right of action. ${ }^{142}$

Thus, the principle unifying the apparently conflicting jurisdictional precedents is not the "persons composing" rule but the "control" or "real party" concept.143 The members of joint stock companies, limited partnership associations, and general partnerships "count" for diversity purposes because all the members exercise management powers. This control is manifested in several ways: in the management role of the respective members, their rights with respect to entity property, their ability to effect dissolution of the entity, their liability for the entity's debts and obligations, and in their capacity to sue and be sued on behalf of the entity. Corporate shareholders and trust beneficiaries, in contrast, have only "equitable" interests in their respective entities. Because limited partners do not enjoy the requisite control over the partnership, ${ }^{144}$ they have only an "equitable" interest in proceedings brought by or against the partnership, and thus, like corporate shareholders and trust beneficiaries, should not be counted for diversity purposes. ${ }^{145}$ The result in Colonial Realty, far from expanding the diversity jurisdiction, is but an application of a principle underlying the Supreme Court's diversity jurisdiction decisions over the past 125 years.

\section{B. The Statutory Policy}

At an earlier time, the Carlsberg Resources rule, it is clear, would have been in complete harmony with Supreme Court diversity jurisdiction doctrine. In the Deveaux case, decided in 1809 , the Supreme Court held that a suit against a corporation was, "in fact and in law," a suit against the corporation's shareholders. ${ }^{146}$ The Marshall Court's departure from Deveaux can be viewed as an exercise in purposive statutory interpretation. Although longstanding judicial interpretation (with the exception of the apparently aber-

112 Robinson v. Smith, 3 Paige Ch. 222 (N.Y. 1832). "The directors are the trustees or managing partners, and the stockholders are cestui que trusts . . . Id. at 232. See Comment, Standing of Limited Partners to Sue Derivatively, 65 Colum. L. Rev. 1463, 1469 (1965).

is Thus it makes sense to have jurisdiction depend upon the citizenship of the directors of a corporation even though the corporation is itself a distinct entity. A corporation itself cannot act. Control of the corporation is exercised through its agents: the directors, acting collectively. See H. Ballantine, Corporations 119, 137 (rev. ed. 1946).

i" See text and notes at notes 127-132 supra.

is The courts have noted that the characteristics of limited partners make them significantly more like shareholders than general partners. See, e.g., Klebanow v. New York Produce Exch., 344 F.2d 294, 297 (2d Cir. 1965) (Friendly, J.) ("[I]n the main, a limited partner is more like a shareholder . . . ."); Ruzicka v. Rager, 305 N.Y. 191, 197-98, 111 N.E.2d 878, 881 (1953) (position of limited partner is "analogous to that of a corporate shareholder").

iN See text and notes at notes 16-18 supra. 
rant Letson decision) precluded treating corporations as "citizens," 147 nothing in the statute or the Constitution demanded that jurisdiction be determined by reference to the citizenship of all the shareholders. Statute and Constitution permitted, and the statute's purpose of protecting litigants from local bias dictated, the opening of the diversity jurisdiction to corporations. Justice Grier said in Marshall:

The right of choosing an impartial tribunal is a privilege of no small practical importance, and more especially in cases where a distant plaintiff has to contend with the power and influence of great numbers and the combined wealth wielded by corporations in almost every state. It is of importance also to corporations themselves that they should enjoy the same privileges, in other states, where local prejudices or jealousy might injuriously affect them..$^{148}$

The Marshall Court's statement expresses the traditional view of the policy behind the diversity jurisdiction. ${ }^{149}$ The diversity jurisdiction has been attacked by many modern commentators as unnecessary and unwise, ${ }^{150}$ and has been defended on grounds surely undreamed of by the Framers and original legislators. ${ }^{151}$ The Carlsberg court was not, of course, guided by the policy underlying the statute. Rather the court embraced the modern view, sanctioned, the court thought, by Bouligny, that strong policy considerations extraneous to the statute argue against any "expansion" of the diversity jurisdiction. Those policy reasons-overcrowded federal dockets ${ }^{152}$ (and the resultant delay in vindicating litigants' rights) and deference to state courts as the preferred oracles of state law ${ }^{153}$ - may be compel-

${ }^{147}$ See text and notes at notes 23,27 supra.

is 57 U.S. at 329.

(4) See The Federalist No. 80 (A. Hamilton).

150 See, e.g., American Law Institute, Study of the Division of Jurisdiction between State and Federal Courts 458-64 (1969) [hereinafter cited as ALI Study]; H. Friendiy, Federal Jurisdiction: A General View 144-46 (1973); Frankfurter, A Note on Diversity Jurisdiction-In Reply to Professor Yntema, 79 U. PA. L. REv. 1097 (1931).

151 These include the arguments that the quality of justice in the federal courts is superior to that of the state courts, Moore \& Weckstein, Diversity Jurisdiction: Past, Present and Future, 43 TEx. L. REv. 1, 21-23 (1964); that the federal and state courts can form a valuable "partnership" in improving the quality of justice, $i d$. at 25; that the exposure to federal court enhances the competence of lawyers otherwise limited to local practice, Wright, The Federal Courts and the Nature and Quality of State Law, 13 WAYNE L. REv. 317, 327 (1967); and that federal adjudication of multi-state controversies "like student-lunch programs . . . is a socially beneficent service which the federal government should extend when it is constitutional to do so." Id.

152554 F.2d at 1256-57.

153 Id. at 1257 . 
ling arguments for amending the statute, but they are scarcely proper guides for courts interpreting the present version. Judge Friendly has articulated similar concerns in the literature and has cogently stated the case against the diversity jurisdiction; ${ }^{154}$ yet in his role as judge he has quite properly given full effect to the (in his view mistaken) legislative judgment informing the statute. ${ }^{155}$ Nor is the diversity statute a legislative enactment that might be avoided because it has outlived its purpose. There is sufficient evidence that the threat of prejudice to out-of-state litigants remains a real one..$^{156}$

It could be argued, by analogy to Strawbridge, that the protective policy of the statute does not require a federal court to try an action involving a limited partnership so long as one of the limited partners is a co-citizen of a party on the other side of the litigation. The Strawbridge rule was apparently predicated on the theory that identity of citizenship between any two opposing parties guaranteed impartiality because the state court could not favor a forum state citizen without hurting another. ${ }^{157}$ That rationale might also be thought applicable to cases in which a party is a co-citizen of a nonparty who has an adverse interest in the outcome of the litigation. This argument should be rejected. First, the complete diversity requirement attributed to Strawbridge is limited to the actual parties to the controversy for good reason: persons only beneficially interested in a lawsuit (be they shareholders, trust beneficiaries, or limited partners) generally will not be known to the court. Second, application of the complete diversity rule very often outstrips the rule's rationale. The presence of a non-diverse opposing party does not protect a party who is not a citizen of the forum state, nor does it protect the forum state citizen whose stake in the litigation is minor by comparison with the stake of his co-citizen opponent. The rule is basically unsound and should be kept within its traditional boundaries.

ist See H. Fraendly, Federal Jurisdiction: A General View 144-46 (1973).

155 Judge Friendly authored the court's opinion in Colonial Realty.

ist See Shapiro, Federal Diversity Jurisdiction: A Survey and A Proposal, 91 Harv. L. REv. 317, 329-32 (1977). The commentary accompanying the ALI Study reached the conclusion that the traditional justification for diversity jurisdiction remains at least partially valid today. ALI STUDY, supra note 150 at 105-11. Finding that there was still the risk (or at least fear of the risk) of prejudice to out-of-state litigants, the ALI stated that "it would be hard to justify total abolition of an existing jurisdiction while there remains risk of the very kind of prejudice against which the federal judicial power was originally designed to provide protection." Id. at 106-07.

157 The soundness of the Strawbridge rule is open to serious question. See Currie, supra note 8, at 18-34. The ALI concluded that the Strawbridge rule is not a constitutional mandate and hence could be circumvented by legislation expanding diversity. ALI STUDY, supra note 150 , at $426-36$. 
Given the policy of the statute, a convincing argument can be made that some forms of unincorporated business association should be treated as citizens in the same manner as corporations. ${ }^{158}$ This argument, however, has been foreclosed by Bouligny, in which the Court, though acknowledging the force of the policy argument for extending entity citizenship, held that policy arguments alone could not justify judicial assumption of a role the Court regarded as reserved to Congress. ${ }^{159}$ Within that constraint, the approach most consistent with the statutory policy is the "real party" approach advocated by Judge Hunter in his Carlsberg dissent.

\section{Applying the Real Party Rule}

In suits by or against a limited partnership, the "real parties" on the partnership side are those who manage the partnership and whose personal resources stand behind the partnership's debts. In determining diversity, a court should look to the citizenship of these parties - the general partners. When an action is brought in district court, or removal to district court is sought, the party invoking federal jurisdiction has the burden of pleading facts necessary to establish jurisdiction. ${ }^{160}$ The party seeking to establish diversity jurisdiction in a limited partnership case could generally do so by averring that the entity is a limited partnership and that the citizenship of all those persons identified in the partnership agreement as general partners is diverse from that of all the opposing parties.

The characterization found in the partnership agreement will not always be conclusive, however. The rationale for generally disregarding the citizenship of limited partners would seem to demand that the courts count for diversity purposes purported limited part-

${ }^{158}$ See Mason v. American Express Co., 334 F.2d 392 (2d Cir. 1964). The ALI adopted the approach of treating unincorporated associations as entities for diversity purposes. ALI Study, supra note 150, at 114-16 (commentary on proposed Judicial Code § 1301(b)(2)).

Partnerships, business trusts, and limited partnerships can sometimes be viewed as having distinct identities apart from that of their individual members. A limited partnership, which must be organized pursuant to publicly filed certificates of limited partnership, can be said to have a kind of geographical identity. This geographical identity may well benefit the limited partnership in litigation in its "home" state against out-of-state parties. Similarly, the partnership might be subject to discrimination in actions in a foreign forum, even though some of the general partners who are personally liable are citizens of that state. $C f$. Marshall v. Baltimore \& Ohio R.R., 57 U.S. (16 How.) 314, 329 (1853) (concerning potential dangers of prejudice for and against a corporation in litigation with a party from another state). The argument for treating limited partnerships as citizens is stronger than for general partnerships since a limited partnership, or a party bringing an action against it, often cannot create federal jurisdiction by resorting to a class action because the limited and general partners will in many cases have divergent interests. See note 66 supra.

${ }^{159}$ See text and note at note 55 supra.

${ }^{160}$ See Hanford v. Davis, 163 U.S. 273 (1896). 
ners who exercise substantial managerial control over partnership affairs. If the jurisdictional averment is challenged, or if the court has reason to suspect the status of one or more limited partners, the court will have to determine whether a non-diverse limited partner has been granted under the partnership agreement, or has in fact exercised, such managerial control that he should be deemed a "real party."' 161 This qualification on the jurisdictional rule corresponds to both the "conduit" exception to the representative party rule ${ }^{162}$ and the "collusive appointment" exception to the rule for determining diversity in cases involving guardians. ${ }^{163}$

The question remaining is how the district court should go about determining whether a limited partner is a "real party" to the action. One reason for counting a limited partner who exercises management powers is that he is in fact a representative of the partnership. A second reason has to do with the risks the partner runs as a price for meddling in management matters. Because a limited partner, under the U.L.P.A., loses the privilege of limited liability by exercising too much control, ${ }^{164}$ a managing limited partner has a far greater financial stake in the partnership than his brethren limited partners. Since the latter rationale for counting the partner is at least as compelling as the former, a partner should be deemed a real party to an action involving the limited partnership if he has exercised such control over partnership affairs that he runs a substantial risk of being held personally liable for partnership debts in the event the partnership becomes insolvent. This is necessarily a matter of guesswork, for the court cannot know how or where or under what state law ${ }^{165}$ the limitation on the partner's liability might someday be tested. A rule of convenience is needed, and the

161 If the defendant challenges federal jurisdiction, the plaintiff has the burden of defeating defendant's objection. McNutt v. McHenry Chevrolet Co., 298 U.S. 178 (1936); Ray v. Bird \& Son \& Asset Realization Co., 519 F.2d 1081 (5th Cir. 1975). Similarly, when the defendant seeks removal to district court, he has the burden of showing that the elements of plaintiff's allegations that would defeat jurisdiction are so baseless as to fraudulently deprive him of access to federal court. Rosario v. Waterman Steamship Corp., 158 F. Supp. 537 (S.D.N.Y. 1957); see Wecker v. National Enameling Co., 204 U.S. 176 (1906).

162 See note 107 supra.

${ }^{103}$ See, e.g., O'Brien v. Avco Corp., 425 F.2d 1030 (2d Cir. 1969) (construing 28 U.S.C. $\S$ 1359 (1970)); McSparran v. Wiest, 402 F.2d 867 (3d Cir. 1968), cert. denied, 395 U.S. 903 (1969).

${ }^{36}$ See U.L.P.A. $\$ 7$.

${ }^{165}$ If the limited partners's status as such for liability purposes is in issue in the action against the partnership there is no uncertainty as to the law under which that issue is to be decided, for the court would simply look to the forum state's choice of law rules. Klaxon v. Stentor Elec. Mfg. Co., 313 U.S. 487, 496-97 (1940). If, however, the plaintiff is asserting that the limited partner is personally liable for plaintiff's injury, the limited partner will be a named party defendant, thus avoiding the inquiry into whether he is a "real party." 
most obvious choice is to test the partner's status by the law of the state of the partnership's organization, ${ }^{166}$ which is perhaps the law that is most likely to apply in the event the partner's status is put to the test.

In cases in which the averment of jurisdictional facts is controverted by the claim that one or more non-diverse limited partners should be considered a general partner for diversity purposes, extensive threshold litigation could ensue. ${ }^{167}$ The possibility of such pretrial litigation might seem to argue against applying a limited partnership counterpart to the conduit exception. The American Law Institute, in its proposed revision of the Judicial Code, posited as a rule of drafting a judicial statute: "It is of first importance to have a definition so clear that it will not invite extensive threshold litigation over jurisdiction." 168 Similarly, in his critique of the ALI proposal, Professor Currie noted epigramatically that "[j]urisdiction should be as self-regulated as breathing" because jurisdictional litigation is "essentially a waste of time and resources." 169 A jurisdictional test that relies on indicia of control and potential liability would appear to fly in the face of this unquestionably sound approbation of pretrial jurisdictional litigation.

This objection is not persuasive, however. A certain amount of

165 Two related problems arise under this approach. The first of these, an objection raised by the majority in Carlsberg Resources, is that the limits of federal jurisdiction will vary with "the vagaries of state law." 554 F.2d 1254, 1261 (3d Cir. 1977). This variation of jurisdictional access from state to state, however, is hardly unique to this rule. In almost any context involving multiple parties to suit, state law-whether substantive or procedural-is likely to have an impact on a party's ability to invoke diversity jurisdiction. See text and notes at notes 113-114 supra. The second concern is that under the law of some states, the criteria for imposing liability on a limited partner might depart from the concept of control, thus taking a test focusing on liability outside of the rationale for the real party rule. Although some states are more liberal than others in permitting limited partners to participate in the control of the partnership without incurring liability as general partners, see, e.g., CAL. CoRP. Code $\S$ 15507 (West 1977) (permitting limited partners to vote on certain managerial decisions without forfeiting limited liability), no state has yet adopted a limited partnership act which frames the test of liability in terms other than control of the business. This does not mean, of course, that a limited partnership act (or a statute governing a similar business entity) could not embrace a liability test substantially independent of control. In such a case the court would be required to forge, by analogy to the U.L.P.A. and to the factors originally articulated in Marshall, a "real party" test in terms of other indicia of control.

167 The district court need not dispense with jurisdictional questions on the basis of the pleadings alone. The court will often look to the pleadings and affidavits, C. WRIGHT, HANDBOOK OF THE LAW OF FEDERAL CouRTS 129 \& n.9 (3d ed. 1976); where jurisdiction has been challenged, however, the court has the option of making the factual inquiry itself or submitting the question to a jury. C. WRIGHT, supra at 329. If the jurisdictional inquiry goes to the merits of the case, the parties might have a right to jury trial. See Note, Trial by Jury of Preliminary Jurisdictional Facts in Federal Cases, 48 IowA L. Rev. 471 (1963).

${ }^{168}$ ALI STUDY, supra note 150, at 128.

160 Currie, supra note 8 , at 1. 
threshold litigation is inevitable under the present jurisdictional statutes. Determining whether a non-diverse limited partner should be treated as a general partner for diversity purposes is no more complicated than deciding whether a guardian has been collusively appointed, or whether a representative is a mere "conduit" for the enforcement of another's rights-threshold tasks which the federal courts routinely confront. The objection is, moreover, essentially irrelevant. This comment addresses not a proposed jurisdictional statute, but an existing one. Once it is determined, as a matter of statutory interpretation, that jurisdiction turns on the citizenship of the real parties to the controversy, the burden on the federal judiciary of determining who those parties are is an unavoidable one. ${ }^{170}$

\section{The Analogous Case of Business Trusts}

The foregoing analysis has implications for determining diversity jurisdiction in cases involving business trusts. The "control" principle gleaned from the cases would seem to require the courts to take into account the beneficiaries' rights or powers of management.

Recent cases involving real estate investment trusts (REITs) have viewed the matter as involving a choice from among three possible rules: the corporate-entity approach, the special rule applicable to trusts, ${ }^{171}$ and the unincorporated association rule of

170 This seemingly inevitable complexity might be mitigated by an appropriate adjustment of the presumptions and burdens of proof which are associated with establishing diversity jurisdiction. Once the party invoking jurisdiction alleges diversity of citizenship as to the general partners, the burden of proof could be shifted to the party opposing jurisdiction to establish that a limited partner whose citizenship would destroy diversity is in fact a general partner. The court could decide the question on the basis of affidavits submitted by the parties and could require the party opposing jurisdiction to meet a summary judgment standard of proof to defeat jurisdiction. Cf. St. Paul Mercury Indemnity Co. v. Red Cab Co., 303 U.S. 283, 289 (1938) ("It must appear that the claim is really for less than the jurisdictional amount to justify dismissal.") The result of this inquiry at the pleading stage would then be conclusive on the issue of jurisdiction, even if at trial a limited partner is ultimately adjudged to have general partner status. Cf. Rosado v. Wyman, 397 U.S. 283 (1970) (determination of jurisdictional amount conclusive in spite of subsequent lesser judgment). See also C. WRIGHT, HandBOOK OF THE Law of Federal CourTs 127 (3d ed. 1976) (arguments for conclusive determination at pleading stage). The Supreme Court has approved the practice, in an analogous context, of trying jurisdictional issues in a truncated fashion when those issues might overlap with issues on the merits. In Smith v. Sperling, 354 U.S. 91 (1957), the Court said that "the proper course" to determine the issue of management antagonism to the financial interests of a corporation, for the purpose of aligning parties in a derivative action preliminary to testing for diversity, "is not to try out the issues presented by the charges of wrongdoing but to determine the issue of antagonism on the face of the pleadings and by the nature of the controversy." Id. at 96.

${ }^{171}$ See text and notes at notes 138-140 supra. 
Chapman and Bouligny. The courts have determined that Bouligny precludes treating REITs as entities for diversity purposes, and that the business character of REITs makes the ordinary trust rules inapplicable. ${ }^{172}$ As authority for distinguishing between business trusts and ordinary trusts courts have relied ${ }^{173}$ on the Supreme Court's opinion in the case of Morrissey $v$. Commissioner, ${ }^{174}$ which held that business trusts should be taxed as corporations and not as traditional trusts because the beneficiaries use such trusts not for holding and conserving capital, but as vehicles for profit-seeking venture. ${ }^{175}$ They have refused to apply the ordinary trust citizenship rule to business trusts because the provisions of business trust agreements, unlike those of ordinary trusts, give the beneficiaries authority to limit the trustee's freedom to dispose of trust property, as well as the power to remove the trustee without cause ${ }^{178}$ and to amend the trust agreement.

In some of these cases, the courts may have been quite correct in finding that it is improper to look to the citizenship of the trustees. In those cases in which the trust agreement granted the beneficiaries broad powers over the trustee, the result might have been the same had the courts applied the traditional rules of trust citizenship. The trustees of such trusts satisfied the requirement of holding legal title to the trust property, but they may have been mere conduits through whom the beneficiaries enforced their rights. Thus under existing jurisdictional precedents the beneficiaries might have been regarded as the relevant parties for diversity purposes. ${ }^{177}$ It would be a mistake, however, to say that the courts have been applying the "conduit exception" sub rosa or that they have been using the kind of "real party" approach suggested by Judge Hunter in Carlsberg Resources. Rather, the courts seem to emphasize those

172 See, e.g., Carey v. U.S. Industries, 414 F. Supp. 794 (N.D. Ill. 1976); Lincoln Assocs., Inc. v. Great Am. Mortgage Investors, 415 F. Supp. 351 (N.D. Tex. 1976); Jim Walter Investors v. Empire-Madison, Inc., 401 F. Supp. 425 (N.D. Ga. 1975).

${ }_{133}$ See, e.g., Jim Walter Investors v. Empire-Madison, Inc., 401 F. Supp. 425, 429 (N.D. Ga. 1975); Fox v. Prudent Resources Trust, 382 F. Supp. 81, 92 (E.D. Pa. 1974). In Lee v. Navarro Savings Ass'n, 416 F. Supp. 1186 (N.D. Tex. 1976), the court stated specifically that the choice of jurisdictional rule should turn on the tax status of the trust.

174296 U.S. 344 (1935).

${ }^{175} I d$. at $356-57$.

${ }^{176}$ See, e.g., Jim Walter Investors v. Empire-Madison, Inc., 401 F. Supp. 425, 428 (N.D. Ga. 1975); Larwin Mortgage Investors v. Riverdrive Mall, Inc., 392 F. Supp. 97,100 (S.D. Tex. 1975).

177 See note 107 supra. Reliance on the "conduit" exception is not really an adequate substitute for examination of the relative rights and liabilities of the trustees and beneficiaries. The trust rules require looking to either the trustees or the beneficiaries, but not to both. Where the trustees and beneficiaries together are managing the trust business, however, both should be counted for diversity purposes. 
features of the trustee-beneficiary relationship that justify labeling the trust a "business" trust, but which features may cumulatively fall far short of constituting managerial control in any real sense. The courts have not said, that is, that the beneficiaries count for diversity purposes because they are the "real parties," 178 but that the beneficiaries, as members of unincorporated "business" associations, must be counted under Bouligny.

Bouligny should not be regarded as dispositive of all business trust cases. The determination of proper parties for diversity purposes should not turn on whether the entity is of a "business" character, but on the allocation of rights and liabilities between the beneficiaries and the trustees. Analysis of the cases from the perspective of the "real party" principle suggests that some of the recent REIT cases may have been decided incorrectly. If a beneficiary of a business trust is truly a passive investor who has no significant voice in the management of the trust, like the limited partner he should not be deemed a party to the action. ${ }^{179}$ Trust agreement terms that permit the beneficiaries to remove the trustees or to prevent transfers of trust property do not seem to vest the management of the trust in the beneficiaries; such provisions only give beneficiaries certain powers that corporate shareholders commonly wield. ${ }^{800}$

Determining the real parties in interest is more complicated for business trusts than for limited partnerships because no uniform statutory framework clearly defines the relative rights and responsibilities of the two classes of members. In the case of business trusts,

${ }^{17 \pi}$ But see Chase Manhattan Mortgage \& Realty Trust v. Pendley, 405 F. Supp. 593 (N.D. Ga. 1975). In that case the court turned the "real party" approach on its head, concluding that since the citizenship of the beneficiaries was controlling, they must be the real parties to the suit. Id. at 596.

17. Under the theoretical model of the business trust the role of the beneficiaries is clearly distinguishable from that of the shareholder in a joint stock company. The shareholders of a joint stock company choose and control the company's managers, who act as agents of the shareholders. Crane \& Bromberg, supra note 32 , at 179 n.19. Business trusts, on the other hand, are non-statutory variations of traditional trusts. The Supreme Court, in Hecht v. Malley, 265 U.S. 144 (1924), defined a business trust as "an arrangement whereby property is conveyed to trustees, in accordance with the terms of an instrument of trust, to be held and managed for the benefit of such persons as may, from time to time, be the holders of transferable certificates issued by the trustees . . . Id. at 146. The business trust differs significantly from both the joint stock company and the general partnership in that the beneficiaries are not co-owners of the trust property. RowLEY \& Sive, supra note 32, at 632, 634 . Legal title to trust property is vested in the trustees, while the beneficiaries have equitable title only.

180 These powers are also comparable to those which limited partners may wield consistently with their limited partner status under more liberal limited partnership acts. See note 166 supra. 
the elements of control and potential personal liability do not mesh as neatly as they do in the limited partnership context. Some states, as a matter of public policy, do not permit investors in business trusts to limit their liabilities at all, regardless of whether they exercise managerial control. ${ }^{181}$ Most states recognize limitations on liability, but will hold liable as general partners beneficiaries who exercise a certain quantum of control (which varies from state to state) over the trust. ${ }^{182}$ Some of the elements of control that might cause a beneficiary to lose his limited liability are similar to those which cause a limited partner to become a general partner: (1) the right to remove the trustees, (2) the right to terminate the trust, (3) the right to modify the terms of the trust, (4) the right to elect trustees, and (5) the right to direct management decisions of the trustees. ${ }^{183}$

Because there is no statutory model of the business trust the courts have no reason to presume that the trustees are the real parties to suits involving business trusts. Therefore, the mere averment that the trustees of a REIT are of citizenship diverse from the opposing parties should not suffice. The court should require the party invoking federal jurisdiction to submit a copy of the trust agreement so that the court can determine the extent of the powers contractually granted the beneficiaries. As in cases involving limited partnerships, the court should also inquire whether non-diverse beneficiaries exercise powers beyond those specified in the trust agreement.

A further consequence of the lack of uniform legislation is that the courts may have to forge a federal "control" test for determining the real parties to controversies involving business trusts. Although the same reasons that mandate reference to state law in limited partnership cases ${ }^{184}$ will often apply here as well, the relevant state law concerning business trusts is less likely to provide a proper guide, either because the state has little or no caselaw on forfeiture of limited liability status, or because beneficiaries' potential personal liability under state law is insufficiently related to the question of their control over enterprise affairs.

In cases in which state law seems a poor guide, the district court could compare the rights and powers of the beneficiaries with those possessed by the corporate shareholders in Marshall and by the

\footnotetext{
181 Crane \& Bromberg, supra note 32, at 173-74.

182 Id. at 174-76.

$1 \times 3$ ROWLEY \& Sive, supra note 32 , at 633.

in See text and notes at notes 164-166 supra.
} 
stockholders of the joint stock company in the Chapman case. If their powers are no more significant than those of corporate shareholders, the beneficiaries should not be counted for diversity purposes. If the beneficiaries can veto or direct trustee management decisions, however, they should be deemed parties. Alternatively, the courts could apply the factors that distinguish limited from general partners under the U.L.P.A. If an investor in a REIT wields such power that he would be deemed a general partner under the U.L.P.A.'s control test, he could be deemed a real party to a controversy involving the REIT.

\section{Conclusion}

Federal diversity jurisdiction extends to those cases in which all parties on one side of the case are of citizenship diverse from that of the parties in opposition. Two distinct lines of Supreme Court authority developed in response to cases involving associations of individuals. The Court's decision in Marshall v. Baltimore \& Ohio Railroad resolved the confusion over whether corporations could be treated as "citizens" and provided a definitive jurisdictional rule that was ultimately codified over 100 years later in 28 U.S.C. $\S$ 1332(c). The Court, however, declined to extend the Marshall doctrine to grant presumptive state-of-formation citizenship to unincorporated associations. Instead, the Court, in Chapman v. Barney and Great Southern Fire Proof Hotel Co. v. Jones, held that such associations may not be deemed citizens, but must satisfy the complete diversity requirement with respect to all the "persons composing" the association. The Court has steadfastly adhered to this rule, reaffirming it most recently in United Steelworkers of America v. R.H. Bouligny, Inc.

The Second Circuit, in Colonial Realty Corp. v. Bache \& Co., departed from the tradition of dogmatic application of the Chapman-Great Southern rule and held that in suits involving limited partnerships the citizenship of only the general partners is relevant for diversity purposes. The court relied on the statutory distribution of rights, powers, and responsibilities between the general and the limited partners in concluding that the latter should be disregarded in determining diversity. Although the decision has been followed by courts in the Second and Fourth Circuits, the Third Circuit, in Carlsberg Resources Corp. v. Cambria Savings \& Loan Association, reached a contrary result, finding that Colonial Realty was not a proper interpretation of the "persons composing" test, but an unwarranted expansion of the scope of diversity jurisdiction. The majority in Carlsberg Resources read the body of Su- 
preme Court precedent as conclusively foreclosing an approach that would distinguish between classes of association members.

Although the court in Colonial Realty did not fully develop the reasoning behind its decision, the result in that case stands on solid ground. Examination of Chapman and Great Southern reveals that those cases did not reject a distinction for jurisdictional purposes between classes of association members. On the contrary, the rationale for such a distinction can be culled from a comparison of the seemingly irreconcilable Marshall and Chapman decisions. In Marshall the Court observed that shareholders were not real parties to litigation involving a corporation and hence were irrelevant to the jurisdictional test. In Chapman, on the other hand, the joint stock company's shareholders were clearly the parties controlling the company, and their personal assets stood behind the company's debts. The characteristics that compelled reference to all the association members in Chapman are not found in the case of limited partners, who are analogous to corporate shareholders. A jurisdictional test that looks to the real parties to the controversy not only makes sense of the diversity precedents, but also accords well with the protective policy underlying the diversity jurisdiction, a policy which remains vital today.

In testing for diversity jurisdiction in suits involving limited partnerships-and in actions involving business trusts-courts should disregard those members who have no significant control over the affairs of the enterprise. The determination whether to count limited partners or business trust beneficiaries as parties to the controversy might often involve complex jurisdictional factual investigation, and thus frustrate the desiderata of ease and economy in the application of jurisdictional tests. These concerns are the business of Congress, however, and should not sway the courts from the results demanded by proper interpretation of the statutory grant of diversity jurisdiction. 